\title{
Respons Tests of Leadership Menurut Teori Frank Damazio Pada Mahasiswa Pascasarjana Jurusan Kepemimpinan Kristen STT Harvest Semarang
}

\section{Response Tests of Leadership According to Frank Damazio's Theory of Postgraduate Students in the Department of Christian Leadership STT Harvest Semarang}

\author{
Sonny Eli Zaluchu ${ }^{1) *}$ \\ 1) Pascasarjana Sekolah Tinggi Theologia Baptis Indonesia, Semarang, Indonesia \\ *Penulis korespondensi: sonnyzaluchu@stbi.ac.id
}

Received: 19 July 2018 /Revised: 24 July 2018/Accepted: 30 September 2018

\begin{abstract}
Abstrak
Seorang pemimpin tidak dilahirkan tetapi dibentuk. Tuhan menggunakan sejumlah ujian untuk pembentukan para pemimpin. Tujuannya, selain membekali, ujian dapat memurnikan panggilan, melatih keterampilan dan membuat para pemimpin bergantung pada Tuhan. Dengan demikian, kepemimpinan tersebut dijalankan tidak dengan caranya sendiri tetapi dengan cara dan agenda Tuhan. Sejumlah ujian itu adalah Ujian Waktu, Ujian Firman, Ujian Karakter, Ujian Motivasi, Ujian Kehambaan, Ujian Padang Gurun, Ujian Kesalahpahaman, Ujian Kesabaran, Ujian Kehendak Pribadi, Ujian Integritas, dan Ujian Pemberontakan. Penelitian ini bertujuan untuk mengukur sejauh mana tanggapan pemimpin dalam menghadapi ujian kepemimpinan. Populasinya adalah para pemimpin gereja yang menjadi mahasiswa pascasarjana (S2) Kepemimpinan Kristen di STT Harvest Semarang. Analisis menggunakan nilai $\mu$ dari Confidence Interval menggunakan model eksogenous-endogenous variabel. Hasilnya, level respons pemimpin terhadap ujian kepemimpinan berada di dalam kategori sedang dan ujian padang gurun adalah faktor dominan yang memengaruhi kepemimpinan responden.
\end{abstract}

Kata-kata kunci: ujian kepemimpinan, kepemimpinan kristen, kepemimpinan, pengembangan kepemimpinan.

A leader is not born but formed. God uses tests for the formation of leaders. The goal, in addition to equipping, analyses can refine purity, train skills and make leaders dependent on God. That leadership is exercised not in its way but in God's way and His agenda. Some of the tests are Time Tests, Word Test, Character Test, Motivation Test, Servant Test, Wilderness Test, Misunderstanding Test, Patience Test, Self-Will Test, Integrity Test, and Rebellion Test. This study aims to measure how leaders respond in the face of Leadership Tests. The population is church leaders, who are students of Christian Leadership Postgraduate (S2) in Christian Leadership Program at STT 
Harvest Semarang. The analysis uses $\mu$ values of Confidence Interval using an exogenous-endogenous variable model. As a result, the level of leader's response to the leadership tests is in the medium category, and the wilderness test is the dominant factor affecting their leadership.

Keywords: leadership exams, Christian leadership, leadership, leadership development.

\section{Pendahuluan}

Salah satu kesimpulan penting di dalam penelitian tentang pengembangan pemimpin dan kepemimpinan (leader and leadership development) yang semakin efektif di dalam dua puluh lima tahun terakhir yang ditemukan oleh Day dkk adalah pentingnya proses di dalam pengembangan kepemimpinan (leadership development) baik secara interpersonal maupun intrapersonal. ${ }^{1}$ Oleh sebab itu, pembentukan pemimpin menjadi bagian tak terpisahkan dari pengembangan kepemimpinan itu sendiri. Menarik untuk diteliti lebih lanjut bagaimana pembentukan pemimpin berjalan, proses apa yang harus dilalui, khususnya dalam lingkup kepemimpinan rohani, di mana Tuhan ikut campur tangan dalam pengembangan kepemimpinan. Pembentukan Tuhan atas pemimpin dapat dilakukan dengan berbagai macam cara. Salah satunya adalah dengan membawa pemimpin di dalam situasi ujian yang memproses hidupnya. Yusuf adalah salah satu contoh tokoh Alkitab yang menghadapi ujian tersebut. Penelitian yang dilakukan Djadi dan Riswanto tentang Yusuf misalnya, menemukan bahwa kekuatan visi di dalam diri Yusuf, menciptakan daya tahan di dalam menghadapi setiap proses yang berat hingga akhirnya Yusuf menjadi seorang pemimpin yang berhasil dan terkenal di Mesir. ${ }^{2}$ Akan tetapi tidak semua pemimpin mampu memahami dan memberikan respons terbaiknya setiap kali Tuhan membawa seorang pemimpin memasuki sejumlah ujian di dalam kepemimpinannya. Ada yang berhasil melaluinya seperti Yusuf dan ada pula yang gagal. Penelitian Clinton menyimpulkan bahwa hanya sekitar tiga puluh persen tokoh Alkitab yang berhasil menyelesaikan tugasnya

${ }^{1}$ David V. Day et al., "Advances in Leader and Leadership Development: A Review of 25 Years of Research and Theory," Leadership Quarterly (2014), http://dx.doi.org/10.1016/j.leaqua.2013.11.004.

${ }^{2}$ Dedy Riswanto, Jermia Djadi, "Prinsip-Prinsip Kepemimpinan Yusuf Dalam Menghadapi Perubahan Berdasarkan Kitab Kejadian 37-50," Jurnal Jaffray 8, no. 2 (2010): 47-65, http://dx.doi.org/10.25278/jj7l.v8i2.46 
dengan baik (finishing well) dan lolos di dalam setiap ujian (test) yang Tuhan hadirkan di dalam kehidupan mereka. ${ }^{3}$

Dalam bukunya berjudul The Making of A Leader, Damazio merumuskan terdapat sejumlah ujian sebagai Tests of Leadership yang Tuhan hadirkan untuk menguji, membentuk dan mempersiapkan pemimpin. ${ }^{4}$ Ujian-ujian tersebut adalah Ujian Waktu, Ujian Firman, Ujian Karakter, Ujian Motivasi, Ujian Kehambaan, Ujian Padang Gurun, Ujian Kesalahpahaman, Ujian Kesabaran, Ujian Kehendak Pribadi, Ujian Integritas, dan Ujian Pemberontakan. Penelitian ini mencoba melakukan eksplorasi respons pemimpin saat menjalani sejumlah ujian dari list Tests of Leadership Damazio. Menarik untuk diteliti, apakah respons pemimpin berada di dalam kategori tinggi dan membawa hasil yang baik atau justru biasa-biasa saja bahkan mungkin rendah. Model hubungan variabel yang dipakai adalah endogenous dan eksogenous variabel. Itulah sebabnya penelitian ini diberikan judul: "Respons Test of Leadership menurut Teori Frank Damazio pada Mahasiswa Pascasarjana Jurusan Kepemimpinan Kristen di STT Harvest Semarang."

\section{Teori Kepemimpinan}

Kepemimpinan haruslah diposisikan pada konsep dan pengertian yang benar. Kouzes dan Posner menangkap problematika tersebut dan berupaya mengubah paradigma orang dari yang masih memegang mitos dan tradisi tentang kepemimpinan, menjadi konsep yang benar secara keilmuan. ${ }^{5}$ Menurut Maxwell, anggapan yang paling lazim muncul adalah kepemimpinan dilahirkan, bukan dibentuk, kepemimpinan hanya milik segelintir orang, kepemimpinan erat kaitannya dengan kedudukan, kekuasaan atau posisi. ${ }^{6}$ Kesalahan anggapan tentang pengertian kepemimpinan seperti ini, pada akhirnya menciptakan motivasi yang salah dalam diri setiap orang untuk menjadi pemimpin demi mengejar kehormatan, kedudukan, dan kekuasaan atas orang lain.

\footnotetext{
${ }^{3}$ Buku ini sangat lengkap menjelaskan tentang temuan Clinton di dalam penelitiannya dan langkah-langkah untuk menjadi pemimpin yang bisa finish well. Baca lengkap di J. Robert Clinton, Pembentukan Pemimpin Sejati (Jakarta: Metanoia, 2004).

${ }^{4}$ Frank Damazio, Making of a Leader (Portland, Oregon: City Bible Publishing, 1987), 171-186.

${ }^{5}$ James M Kouzes and Barry Z Posner, Tantangan Kepemimpinan (Jakarta: Interaksara, 2008), 40.

${ }^{6}$ John Maxwell, Mengembangkan Kepemimpinan Di Dalam Diri Anda (Jakarta: Binarupa Aksara, 1995), 2.
} 
Mankletow memunculkan satu pertanyaan mendasar, apakah sebetulnya pengertian yang tepat tentang kepemimpinan $?^{7}$ Pertanyaan tersebut dijawab di dalam berbagai rumusan sebagai berikut.

Kouzes melihat kepemimpinan sebagai sebuah seni yang harus ada di dalam diri seseorang supaya orang-orang yang mengikutinya dapat berjuang bersama-sama mencapai tujuan. Hal ini hanya dimungkinkan terjadi apabila seseorang memiliki pengaruh di dalam dirinya. ${ }^{8}$ Sandersdalam karya klasiknya tentang kepemimpinan rohani, sependapat dengan hal tersebut. ${ }^{9}$ Menurutnya, tanpa pengaruh, seseorang tidak akan mampu memimpin orang lain. Sebab, memimpin adalah bagaimana memengaruhi orang lain. ${ }^{0}$ Sementara Gardner di dalam Blackaby lebih melihat kepemimpinan sebagai proses di mana seseorang mampu bergerak di dalam satu kelompok secara bersama-sama untuk mencapai tujuan. ${ }^{1 l}$ Di dalam kelompok itu terjadi interaksi memengaruhi dan dipengaruhi. Sebagaimana diungkapkan oleh pakar kepemimpinan John Maxwell, bahkan di dalam kehidupan, memengaruhi dan dipengaruhi adalah sesuatu yang secara bergantian kita alami. ${ }^{12}$ Di suatu saat seseorang dapat memengaruhi dan di waktu yang lain, dirinya berada di dalam posisi untuk dipengaruhi. Pada satu bidang seseorang menjadi seorang pemimpin dan di bidang lain dia adalah seorang pengikut dari seorang pemimpin. Jadi, memimpin dan dipimpin adalah natur kehidupan dan tidak ada satu orangpun yang luput dari dialektika tersebut.

Dapat disimpulkan bahwa kepemimpinan tidak terkait dengan usaha memperoleh kekuasaan atau kedudukan, tetapi terikat pada sebuah fungsi yakni bagaimana memengaruhi orang lain. Seseorang yang memiliki kemampuan dalam dirinya untuk membawa pengaruh kepada orang lain dalam mencapai tujuan yang telah ditetapkan bersama, itulah yang disebut pemimpin.

7 James Manktelow, "What Is Leadership?," MindTools 55, no. 1 (2018): 1, diakses

19 Maret 2018, https://www.mindtools.com/pages/article/newLDR_4l.htm.

${ }^{8}$ Kouzes and Posner, Tantangan Kepemimpinan, 59. 2017), 15.

${ }^{9}$ J. Oswald Sanders, Kepemimpinan Rohani, 13th ed. (Bandung: Kalam Hidup,

${ }^{10}$ Sail Lola, Nelly Petronella Tuhumury, "Prinsip-Prinsip Kepemimpinan Transformatif Berdasarkan Kitab Nehemia Dan Implikasinya Bagi Kepemimpinan Rohani Masa Kini," Jurnal Jaffray 8, no. 2 (2010): 66-87, http://dx.doi.org/10.25278/jj7l.v8i2.48

${ }^{11}$ Henry Blackaby and Richard Blackaby, Kepemimpinan Rohani (Jakarta: Gospel Press, 2005), 33.

${ }^{12}$ Maxwell, Mengembangkan Kepemimpinan Di Dalam Diri Anda, 2. 


\section{Kepemimpinan Kristen}

Kepemimpinan Kristen berbeda dengan kepemimpinan pada umumnya. Ia adalah sebuah kepemimpinan rohani yang berlandaskan prinsip-prinsip Firman Tuhan. ${ }^{13}$ Maka penetapan tujuannya bukan hanya fokus pada organisasi dan kepentingan manusia tetapi menurut Clinton lebih pada refleksi kepentingan Allah melalui manusia. ${ }^{14}$ Inilah yang dimaksudkan oleh Blackaby sebagai agenda Allah, di mana pemimpin menggerakkan pengikutnya menurut agenda Allah. ${ }^{15} \mathrm{Jadi}$, sesungguhnya seorang pemimpin rohani tidak membawa misi pribadinya, melainkan menjalankan tugas kepemimpinan dari Tuhan. Hidupnya digerakkan oleh tujuan ilahi. Ketika pemimpin rohani melayani, pemimpin tersebut tidak sedang melayani organisasi atau kepentingan tertentu. Semua pekerjaan yang dilakukannya adalah refleksi kepentingan Tuhan.

Campur tangan Tuhan adalah faktor yang membedakan kepemimpinan alamiah di dunia dengan kepemimpinan rohani. Stott memandang keduanya berbeda. Fungsi kepemimpinan manajerial di perusahaan tidaklah identik dengan fungsi kepemimpinan rohani di dalam gereja dan lingkupnya. Meskipun konsep kepemimpinan samasama dipakai oleh gereja dan dunia, tidak lantas paham kepemimpinan di kedua lingkup tersebut sama. ${ }^{16}$ Berdasarkan argumentasi tersebut, walaupun kepemimpinan adalah seni memengaruhi seseorang, namun prinsip prinsip dasar dan praktik kepemimpinan sekular berbeda dengan kepemimpinan rohani. Perbedaan tersebut dilihat oleh Clinton yang merumuskan bahwa seorang pemimpin rohani adalah orang yang diberdayakan Tuhan melalui sebuah kapasitas dan menerima tanggung jawab tertentu bagi satu kelompok yang ditetapkan Tuhan untuk mencapai tujuan-tujuan Allah. ${ }^{17}$ Terlihat bahwa salah satu faktor pembeda kepemimpinan alamiah dengan kepemimpinan Kristen adalah tujuan yang hendak dicapai.

Clinton melihat bahwa seorang pemimpin dituntut mengembangkan talentanya hingga pada level maksimal dan bertanggung jawab atas talenta itu kepada Tuhan, supaya penggunaannya selaras dengan kehendak-Nya saja. Dari sini terlihat bahwa kapasitas yang dimiliki oleh seorang pemimpin rohani tidak berasal dari dalam dirinya atau atas usahanya sendiri, tetapi diberikan dan diberdayakan oleh Allah yang telah memilih dan membentuknya. Demikian halnya dengan tanggung jawab,

\footnotetext{
${ }^{13}$ Heni J. Nouwen, In the Name of Jesus: Reflections on Christian Leadership, 34.

${ }^{14} \mathrm{~J}$. Robert Clinton, Pembentukan Pemimpin Sejati, 163.

${ }^{15}$ Blackaby and Blackaby, Kepemimpinan Rohani, 38.

${ }^{16}$ John Stott, Isu-Isu Global - Tantangan Kepemimpinan Kristiani (Jakarta: Yayasan Komunikasi Bina Kasih/OMF, 2005), 472.

${ }^{17} \mathrm{~J}$. Robert Clinton, Pembentukan Pemimpin Sejati, 157.
} 
bukan hanya menyangkut beban pelayanan, tetapi melingkupi kesadaran di hadapan Allah tentang tugas pelayanan tersebut. Dengan demikian dapat disimpulkan bahwa pemimpin rohani adalah pemimpin yang diangkat, diperlengkapi, dan diberdayakan oleh Allah sendiri.

Seseorang yang berada di dalam kepemimpinan umum/sekular mampu mengembangkan kemampuannya secara pribadi dari sifat-sifat alamiah yang dimilikinya maupun melalui berbagai pelatihan untuk meningkatkan keterampilan kepemimpinannya. ${ }^{18}$ Tetapi menurut Sanders kepemimpinan rohani tidak sama dengan kepemimpinan umum/sekular tetapi lebih merupakan satu campuran antara sifat-sifat alamiah dan rohani. Walaupun di dalam kepemimpinan rohani ada sifatsifat alamiah, namun yang membuatnya berbeda dari kepemimpinan alamiah adalah hadirnya unsur yang lebih utama dan melengkapi sifatsifat itu. Unsur utama dan yang melengkapi sifat-sifat itu tidak datang dari dunia tetapi dari Roh Allah untuk satu tujuan membuat pemimpin tersebut mampu mengatasi berbagai rintangan dari luar, bahkan yang ada di dalam dirinya sendiri. Di dalam diri pemimpin rohani ada kuasa rohani yang memampukan seorang pemimpin memenuhi panggilan tugasnya. ${ }^{19}$

Oleh sebab itu, seseorang bisa saja disebut atau menyebut dirinya pemimpin. Tetapi untuk menjadi seorang pemimpin rohani, haruslah dipilih, diproses, dibentuk dan diangkat oleh Allah. Pengangkatan tersebut akan membuat seorang pemimpin memiliki sejumlah indikator yang memperlihatkan sifat-sifat khusus, yang membedakannya dari orang lain. Hal utama yang sangat terlihat adalah dalam hal otoritas. Dengan demikian dapat disimpulkan bahwa seorang pemimpin rohani, tidak menjadi pemimpin atas kehendaknya sendiri tetapi diangkat oleh Tuhan dan bertugas untuk melayani Allah. Dalam rangka mendewasakan seorang pemimpin di dalam panggilan, fungsi dan kecakapannya, Tuhan membawa pemimpin tersebut di dalam proses pembentukan melalui sejumlah ujian yang disebut dengan The Tests of Ministry.

\section{Konsep The Tests of Ministry Frank Damazio dalam Kepemimpinan Kristen}

Dalam bukunya berjudul The Making of A Leader, Frank Damazio merumuskan sejumlah ujian yang harus dilalui oleh seorang pemimpin rohani di dalam proses pembentukan dan penetapan Tuhan. ${ }^{20}$ Ujian tersebut hadir bukan untuk menjatuhkan, melainkan membangun dan

${ }^{18}$ R. A. Heifetz and D. L. Laurie, "The Work of Leadership.," Harvard business review 75, no. 1 (1997): 124-134, https://doi.org/10.1109/EMR.2009.5235495

${ }^{19}$ Sanders, Kepemimpinan Rohani, 17.

${ }^{20}$ Damazio, Making of a Leader, 171-186. 
membuat seorang pemimpin bertumbuh di dalam panggilan, iman dan kapasitas. Melalui ujian demi ujian tersebut, pemimpin dibawa di dalam proses pemurnian di dalam segala aspek hidupnya dan dididik untuk bergantung sepenuhnya kepada Tuhan. Dengan demikian, terbentuk semacam roh takut akan Tuhan sebagai penghormatan atas kedaulatanNya. ${ }^{21}$ Pemimpin yang punya kemurnian di dalam dirinya, yang motivasinya hanya untuk memuliakan Tuhan dan bertujuan untuk memenangkan jiwa-jiwa bagi Tuhan adalah pemimpin yang dipakai Tuhan. Pengotor dan sikap tidak murni dari hati seorang pemimpin seperti kepahitan, keegoisan dan keserakahan serta ambisi, akan disingkirkan dan digantikan dengan kasih.

Beberapa ujian tersebut adalah sebagai berikut:

a. Ujian Waktu (Time Test)

Tes ini menguji pemimpin dalam hal waktu, di mana melalui semua kenyataan yang terlihat, seolah-olah apa yang telah dijanjikan Tuhan di masa lalu begitu lambat digenapi. Uji waktu menempatkan pemimpin untuk menanti penggenapan janji Tuhan dan memaksanya tetap percaya bahwa Tuhan akan bertindak pada waktu yang tepat, dengan cara-Nya dan jalan-Nya. Tes ini bertujuan menumbuhkan iman di dalam diri pemimpin dan memperbesar takaran kepercayaan terhadap Tuhan. Selama "time of delay" pemimpin diajak melihat kemurnian dirinya sendiri.

b. Ujian Firman (Word Test)

Di dalam tes ini, pemimpin diperhadapkan pada situasi yang kelihatannya meniadakan semua kebenaran firman yang selama ini dipercaya dan diterimanya. Seperti memasuki masa gelap dan berada di dalam situasi luar biasa yang bertolakbelakang dengan firman-Nya. Allah ingin melihat seberapa jauh pemimpin ini memegang kuat firman-Nya dan tetap bertahan dalam ketaatan. Allah menggunakan tes ini untuk melatih pemimpin menolak sumber daya dari dirinya sendiri dan hanya bergantung pada kekuatan Tuhan melalui firman-Nya. Ujian ini sangat menantang khususnya bagi pemimpin yang memiliki banyak talenta dan kemampuan.

c. Ujian Karakter (Character Test)

Tes ini menempatkan pemimpin dikelililingi oleh situasi seperti dosa dan kedagingan, yang mencoba menariknya masuk ke dalam situasi tersebut. Dalam hal ini Tuhan menguji seberapa jauh pemimpin mempertahankan kesalehannya dan tetap kuat di dalam takut akan Tuhan. Tujuan Allah adalah untuk melatih manusia batiniah pemimpin

${ }^{21}$ Peniel C. D. Maiaweng, "Tinjauan Teologis Tentang Takut Akan Tuhan Berdasarkan Kitab Amsal Dan Implementasinya Dalam Hidup Kekristenan," Jurnal Jaffray 10, no. 2012 (2012): 118-147, http://dx.doi.org/10.25278/jj7l.vl0il.68 
dan memperlihatkan kepadanya bagian-bagian di dalam dirinya yang masih lemah sehingga hidupnya selalu bergantung dan membutuhkan kasih karunia Tuhan untuk melalui semua hal tersebut. Di sini pemimpin dibentuk Tuhan untuk tetap berdiri di sisi yang seharusnya dan tidak menjadi sama dengan dunia.

d. Ujian Motivasi (Motivation Test)

Tes ini untuk melihat apa saja faktor internal dan eksternal dari pemimpin yang memengaruhi setiap keputusannya, perilakunya atau tindakannya bahkan komitmennya. Tuhan ingin memurnikan motivasi pemimpin dan membentuk nilai-nilai yang benar di dalam dirinya sesuai dengan yang Allah kehendaki. Jangan sampai terjadi tujuan pemimpin adalah untuk memenuhi ambisi dan kepentingan sendiri, melebihi panggilan dan tanggung jawabnya dari Tuhan.

e. Ujian Kehambaan (Servant Test)

Pemimpin melalui tes ini diuji dalam hal kehambaan, apakah pemimpin itu senang dilayani atau melayani, senang tampil atau bekerja tanpa terlihat. Tetapi yang jauh lebih penting adalah apakah pemimpin tidak merasa malu melakukan pekerjaan-pekerjaan yang terlihat kasar atau mengotori bajunya. Dalam tes ini pemimpin juga diuji dengan pergeseran-pergeseran yang ekstrim dari posisi "enak" ke posisi yang "tidak enak". Pemimpin dibawa dalam suasana yang sangat tidak nyaman untuk membentuk watak kepelayanan dan nilai-nilai kehambaan di dalam dirinya. Segala hal seperti gengsi, martabat dan egoisme terkikis dan pemimpin menjadi orang yang sangat peduli kepada orang lain. Otoritas yang besar seringkali menjadi hambatan bagi jenis tes ini. Sasaran dari tes ini adalah pembentukan kualitas kerendahan hati di dalam diri pemimpin.

f. Ujian Padang Gurun (Wilderness Test)

Dalam tes ini Tuhan membawa pemimpin ke dalam "lingkungan gurun" yang kering dan terisolasi. Orang-orang meninggalkannya. Tidak ada kenyamanan di sana. Pemimpin kadang dibiarkan sendiri tanpa kehadiran orang lain. Respons pemimpin terhadap Allah sangat menentukan keberhasilan tes ini. Allah menjadikan tes ini untuk membentuk sikap hidup bertahan dan daya juang di dalam diri pemimpin supaya tidak gampang menyerah dan bertahan di dalam situasi yang sulit. Persoalan kepemimpinan sangat banyak dan dibutuhkan mentalitas pemimpin yang siap dibawa ke padang gurun. Di sini pemimpin membutuhkan tuntunan Allah sepenuhnya supaya dapat mengikuti jalan yang benar dan benar-benar bergantung kepada-Nya melalui kehidupan yang intim dengan Tuhan.

g. Ujian Kesalahpahaman (Misunderstanding Test)

Tes ini menguji komunikasi pemimpin dengan orang-orang yang mengikutinya. Orang-orang menjadi salah menafsirkan atau terjadi 
kesalahan makna sebenarnya dari kata-kata, tindakan, sikap atau motif pemimpin. Dalam hal ini pemimpin dibentuk Tuhan untuk mengoreksi atau memperbaiki diri dan tidak menempatkan kesalahan di pundak orang lain di satu sisi dan di sisi lain. Tuhan membentuk pemimpin dalam hal kecakapan berkomunikasi dengan orang lain. Pemimpin dengan kekuasaan yang besar seringkali mengalami kesulitan menyampaikan idegagasan kepada orang lain karena sifat kekuasaan yang cenderung memerintah daripada membuat orang lain mengerti. Sasaran pembentukan adalah mental dan kerendahan hati pemimpin. Termasuk di dalamnya kesabaran.

h. Ujian Kesabaran (Patience Test)

Tes ini menguji pemimpin jika segala yang direncanakan ternyata tidak sesuai harapan atau jadwal. Orang-orang yang terlibat menjadi tidak sesempurna dan berlangsung situasi di luar kendali yang tidak terekspektasi sebelumnya. Tes ini menempatkan pemimpin menghadapi kesalahan dan kelemahan orang lain. Allah membentuk pemimpin untuk melatih kesabaran pada ukuran yang lebih panjang, melatih pemimpin untuk memikirkan solusi daripada mengumbar emosi atau komplain. Pemimpin dengan karakter keras atau yang selalu menuntut kesempurnaan, membutuhkan waktu lebih lama untuk lolos tes ini.

i. Ujian Kehendak Pribadi (Self Will Test)

Tuhan selalu menghancurkan kehendak dan kepentingan pribadi dari pemimpin yang dipakai-Nya. Tuhan biasanya akan membawa pemimpin untuk mengalami konflik supaya semua kehendak pribadi itu bisa ditekan dan dikendalikan dan pemimpin hanya bergerak memenuhi tugasnya saja. Bahkan di dalam tes ini, pemimpin seringkali membayar harga atas apa yang dilakukan orang lain. Tuhan menuntut pemimpin untuk "berkorban" baik perasaan, tenaga, waktu dan materi. Tujuan Allah adalah menghasilkan pemimpin yang murni dan "mati" terhadap kedagingan dan bersedia berkorban untuk kepentingan orang lain. Contoh Alkitab: Yesus Kristus.

j. Ujian Integritas (Integrity Test)

Integritas adalah apa yang dilakukan pemimpin saat tidak terlihat, apakah yang dikatakan pemimpin telah sesuai dengan perilakunya. Tes ini membentuk pemimpin untuk memiliki sikap tidak goyah (tetap menjadi orang benar) di tengah situasi yang mungkin menjadikannya tidak populer atau ditolak oleh orang lain. Integritas adalah kejujuran terhadap kebenaran, ya di atas ya dan tidak di atas tidak. Allah bertujuan menghasilkan pemimpin yang apa adanya dan menjadi alat luar biasa di tangan-Nya. Allah tidak berkenan kepada pemimpin yang "hipokrit" memakai topeng atau bersandiwara. Kepemimpinan adalah kehidupan yang apa adanya. 


\section{k. Ujian Pemberontakan (Rebellion Test)}

Dalam ujian ini, pemimpin ditempatkan dalam situasi di mana orang-orang yang seharusnya taat dalam kepemimpinan berubah membangkang dan memberontak serta memperlihatkan sikap penentangan secara terbuka. Pemimpin ditolak di mana-mana. Tujuan Allah atas situasi ini adalah membentuk pemimpin untuk mampu menyelesaikan masalah dan menghadapi segala sesuatunya dengan tenang. Pemimpin harus mengevaluasi diri. Ketegasan dan hikmat pemimpin dibentuk di satu sisi sedangkan "kasih bapa" di sisi lain. Allah membentuk pemimpin untuk belajar memahami dan merangkul orang lain.

Tes tersebut di atas adalah sebuah alat yang digunakan Tuhan untuk pembentukan karakter kepemimpinan. Hasilnya adalah pemimpin menjadi dewasa dan kapasitasnya menjadi bertambah. Dengan mengenali sejumlah ujian itu, pemimpin diharapkan dapat memberikan respons yang tepat ketika menyadari dirinya sedang berada di dalam situasi ujian, bukan untuk menghindari melainkan bertahan hingga dinyatakan Tuhan lolos dan lulus dengan hasil memuaskan.

\section{Metodologi Penelitian}

Penelitian ini bertujuan untuk melihat sejauh mana respons Tests of Leadership menurut Teori Damazio di kalangan mahasiswa program Pascasarjana jurusan Kepemimpinan Kristen Sekolah Tinggi Teologi Harvest Semarang.

Jenis penelitian ini adalah kuantitatif dengan memilih survei menggunakan angket sebagai alat pengumpulan data. Responden menilai respons dirinya sendiri terhadap sejumlah item Tests of Leadership yang pernah atau sedang dijalaninya, menggunakan angket dengan skala Likert dengan jawaban A: Sangat Baik; B: Baik; C: Rata-rata; D: Buruk dan E: Sangat buruk.

Variabel penelitian ini terdiri dari endogenous variable dan exogenous variable. ${ }^{22}$ Variabel exogenous adalah variabel yang keragamannya berada di luar model dan yang berperan untuk menjelaskan variabel-variabel lain atau hasil dalam model atau disebut juga variabel bebas. Sementara variabel endogenous adalah variabel yang disebabkan oleh satu atau lebih

\footnotetext{
22 Benjamin M. Bolker, "Combining Endogenous and Exogenous Spatial Variability in Analytical Population Models," Theoretical Population Biology 64, no. 3 (2003): 255-270, https://doi.org/10.1016/S0040-5809(03)00090-X
} 
variabel dalam model atau disebut juga variabel terikat. ${ }^{23}$ Menurut Mustafa, exogenous variable memiliki keragaman dan diposisikan sebagai variabel pemula atau disebut juga variabel bebas di dalam model. Sementara itu, endogenous variable adalah variabel yang keragamannya atau dibentuk atau disusun atau terjadi dengan sendirinya akibat kehadiran exogenous variable (juga disebut sebagai variabel terikat di dalam model). ${ }^{24}$

Variabel Eksogenous di dalam penelitian ini adalah: Ujian Waktu $\left(\mathrm{Y}_{1}\right)$, Ujian Firman $\left(\mathrm{Y}_{2}\right)$, Ujian Karakter $\left(\mathrm{Y}_{3}\right)$, Ujian Motivasi $\left(\mathrm{Y}_{4}\right)$, Ujian Kehambaan ( $\left.\mathrm{Y}_{5}\right)$, Ujian Padang Gurun ( $\left.\mathrm{Y}_{6}\right)$, Ujian Kesalahpahaman $\left(\mathrm{Y}_{7}\right)$, Ujian Kesabaran ( $\left.\mathrm{Y}_{8}\right)$, Ujian Kehendak Pribadi ( $\left.\mathrm{Y}_{9}\right)$, Ujian Integritas ( $\left.\mathrm{Y}_{10}\right)$ dan Ujian Pemberontakan ( $\left.\mathrm{Y}_{11}\right)$. Sedangkan Variabel Endogenous adalah Ujian Kepemimpinan (Tests of Leadership). Hubungan antar variabel digambarkan dalam gambar di bawah ini.

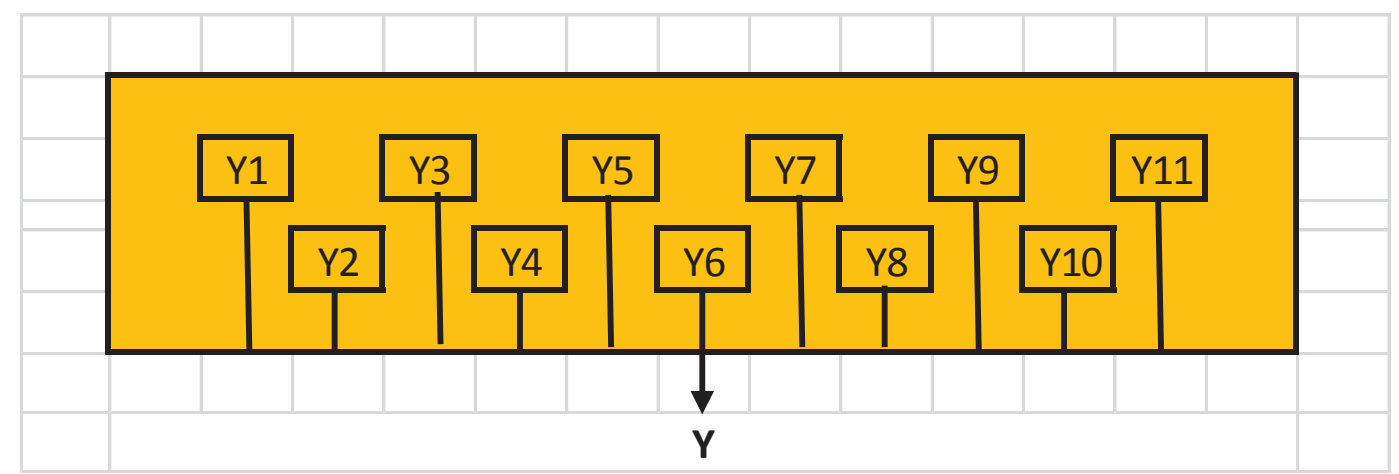

Gambar 1. Hubungan Antar-Variabel

Di mana:

$\mathrm{Y}_{1}$ sd $\mathrm{Y}_{11}$ sebagai Eksonegous Variabel (Indikator pembentuk Y)

$\mathrm{Y}=$ Tests of Leadershipsebagai Endogenous Variabel

Sampel di dalam penelitian adalah mahasiswa program Pascasarjana jurusan Kepemimpinan Kristen di STT Harvest Semarang. Pengambilan data dilakukan pada Semester Genap 2017/2018 pada sebanyak 15 orang responden yang semuanya adalah pemimpin gereja di dalam lingkup pelayanan gereja lokal masing-masing (Tabulasi data terlampir).

Analisis dilakukan dengan menghitung nilau $\mu$ (confidence interval) dari Variabel Endogenous Tests of Leadership (Y). ${ }^{25}$ Nilai $\mu$ adalah sebuah

${ }^{23}$ Johan Wagemans, "Cognitive Psychology," ed. Kimberly Kempf-Leonard, Encyclopedia of Social Measurement (2005): 351-359, diakses 7 April, http://linkinghub.elsevier.com/retrieve/pii/B0123693985004801.

${ }^{24}$ Bambang Prasetyo and Lina M. Jannah, Metode Penelitian Kuantitatif (Jakarta: Raja Grafindo Perkasa, 2008), 43-44.; Sasmoko Eliezer, Bahan Kuliah Metode Penelitian Dan Measurement Mahasiswa S2 Manajemen Pendidikan Di Tana Toraja, 2006. Belum dipublikasikan.

${ }^{25}$ David Moshman, "Exogenous, Endogenous, and Dialectical Constructivism," Developmental Review 2, no. 4 (1982): 371-384. DOI:10.1016/0273-2297(82)90019-3. 
interval yang memberikan informasi tentang estimasi populasi penelitian menggunakan data sampel. ${ }^{26}$ Nilai ini dapat dipergunakan untuk mengamati kecenderungan yang berlangsung di populasi. Dalam menjelaskan kecenderungan variabel, ditetapkan tiga kategori sebagai level respons yakni tidak punya respons (rendah), biasa-biasa saja (sedang) dan sangat responsif (tinggi). Perhitungan dilakukan menggunakan alat bantu komputer melalui program SPSS. Dalam menentukan kategori Eksogenous Variabel $\left(\mathrm{Y}_{\mathrm{n}}\right)$ yang dominan memberi pengaruh pada Endogenous Variabel (Y), dilakukan uji serentak seluruh variabel eksonegous terhadap Y menggunakan analisis Classification and Regression Tree ${ }^{27}$ dengan menetapkan prunning berupa parents 2 dan child 2 pada taraf kepercayaan 95\%. Perhitungan dilakukan dengan metode parametrik setelah menghitung deviation from linearity memenuhi standar linier pada nilai $\alpha>0.05 .^{28}$ Semua variabel di dalam penelitian ini ditetapkan dalam asumsi homogen.

\section{Temuan dan Analisis}

Adapun hasil perhitungan Descriptive Statistic untuk Variabel Tests of Leadership disajikan pada tabel di bawah ini.

Tabel 1. Tabulasi Nilai Descriptive Statistic Variabel Y

\begin{tabular}{|l|r|r|}
\hline \multicolumn{1}{|c|}{ Descriptives } & \multicolumn{1}{c|}{ Statistic } & Std. Error \\
\hline Mean & 39.87 & 1.316 \\
\hline 95\% Confidence Interval Lower Bound & 37.04 & \\
& & \\
\hline 95\% Confidence Interval Upper Bound & 42.69 & \\
& & \\
\hline $5 \%$ Trimmed Mean & 39.91 & \\
\hline Median & 39.00 & \\
\hline Variance & 25.981 & \\
\hline Std. Deviation & 5.097 & \\
\hline Minimum & 31 & \\
\hline
\end{tabular}

${ }^{26}$ Leonard J. Kazmier, Statistik Untuk Bisnis, ed. Wisnu Candra Kristiaji, lst ed. (Jakarta: Erlangga, 2005), 58.

27 Wei Yin Loh, "Classification and Regression Trees," Wiley Interdisciplinary Reviews: Data Mining and Knowledge Discovery 1, no. 1 (2011): 14-23. DOI:10.1016/01697439(91)80113-5.

${ }^{28}$ Sonny Eli Zaluchu, Pengolahan Data Kuantitatif - Pendekatan Quantitative Analysis Melalui Perbandingan (Komparatif), Hubungan (Korelasional) Dan Estimasi (Regresi) Menggunakan SPSS. (Semarang: Golden Gate Publishing, 2018), 62. 


\begin{tabular}{|l|r|r|}
\hline Maximum & 48 & \\
\hline Range & 17 & \\
\hline Interquartille Range & 8 & \\
\hline Skewness & -.191 & 0580 \\
\hline Kurtosis & -1.092 & 1.121 \\
\hline
\end{tabular}

Berdasarkan penetapan Jumlah klas ( $\Sigma \mathrm{k})$ sebanyak 3, maka perhitungan nilai interval $\mathrm{klas} i \mathrm{k}=$ Range $/ \mathrm{Kk}$ diperoleh nilai 5.6 dan ditetapkan menjadi 5. Dengan nilai minimum sebesar 31 dan maksimun 48, maka hasil respons mahasiswa Pascasarjana Kepemimpinan Kristen terhadap Tests of Leadership ditabulasikan seperti tabel di bawah ini.

Tabel 2. Hasil Analisis Confidence Interval Tests of Leadership Mahasiswa Pasca Sarjana Kepemimpinan Kristen STT Harvest Semarang

\begin{tabular}{|c|c|c|c|}
\hline Interval Klas & Kategori & Rentang Nilai $\mu$ & Kesimpulan \\
\hline $31-36$ & Respons rendah & & \\
\hline $37-42$ & Respons Sedang & 37.04 sd 42.69 & Biasa-biasa saja \\
\hline $43-48$ & Respons Tinggi & & \\
\hline
\end{tabular}

Hasil analisis data memperlihatkan rentang nilai Lower Bound dan Upper Bound yakni 37.04 sampai dengan 42.69 terletak pada kategori sedang di dalam tabel klas interval. Artinya, respons mahasiswa program Pasca Sarjana Kepemimpinan Kristen di STT Harvest Semarang, cenderung sedang atau biasa-biasa saja di dalam menjalani setiap item dari Tests of Leadership yang Tuhan hadirkan di dalam perjalanan hidup mereka sebagai pemimpin yang sedang dipersiapkan Allah. Pada taraf kepercayaan 95\% nilai mean sampel 39.87 berada di dalam rentang nilai $\mu$. Sebagaimana dijelaskan pada bagian metode bahwa salah satu manfaat dari nilai confidence interval $(\mu)$ adalah prediksi populasi menggunakan mean sampel, maka dapat diduga bahwa nilai tersebut mencerminkan kondisi biasa-biasa saja pada populasi, yakni seluruh mahasiswa di setiap angkatan yang mengikuti program Pascasarjana Kepemimpinan Kristen di STT Harvest Semarang.

Temuan penelitian di dalam kategori sedang seperti tabel di atas dapat terjadi karena mahasiswa STT Harvest Semarang sebagai pemimpin-pemimpin Kristen yang sedang di bentuk Tuhan, belum memahami arti pentingnya pembentukan kepempimpinan melalui sejumlah ujian yang dipergunakan Tuhan melalui perjalanan hidup kepemimpinan. Situasi ini dapat diatasi dan atau ditingkatkan, dengan 
memberikan wawasan mengenai item-item Tests of Leadership dari Damazio baik melalui ceramah/seminar, muatan di dalam materi perkuliahan dan mentoring. Sebab, dengan menyadari adanya Tests of Leadership, pemimpin akan dapat memberi respons terbaiknya dan menjalani proses tersebut dengan hasil yang memuaskan.

Sedangkan hasil perhitungan Classification and Regression Tree (C\&RT) sesuai prunning yang telah ditetapkan dari Eksogenous Variabel yang paling dominan memengaruhi Tests of Leadership mahasiswa program pascasarjana Kepemimpinan Kristen STT Harvest Semarang, dilaporkan pada gambar berikut ini.

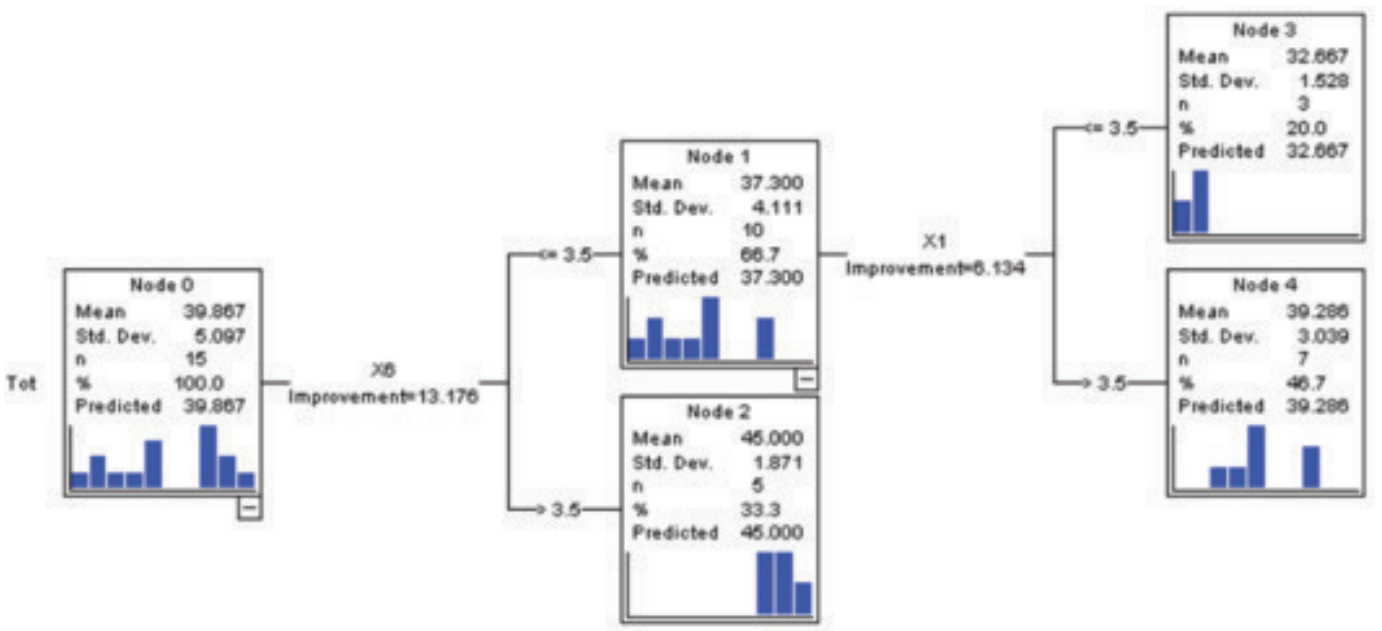

Gambar 2. Hasil Analisis C\&RT pada Eksogenous Variabel

Gambar C\&ET memperlihatkan hasil pengujian serentak seluruh variabel eksogenous terhadap variabel endogenousnya. Ujian Padang Gurun/Wilderness Test $\left(\mathrm{X}_{6}\right)$ adalah variabel yang paling dominan memengaruhi respons mahasiswa di dalam menjalani Tests of Leadership. Nilai improvement $\mathrm{X}_{6}$ terlibat lebih besar dibandingkan variabel lain, yakni 13.176. Sementara Ujian Padang Gurun sendiri ikut dipengaruhi oleh Ujian Waktu (Time Test) atau $X_{1}$ yakni kesabaran menanti janji Tuhan. Fakta tersebut mengindikasi adanya hubungan langsung. Sesuai landasan teori, Ujian Padang Gurun adalah cara Tuhan membentuk seorang pemimpin untuk berada di tanah kering, dan sendirian. Tuhan menempatkan pemimpin di dalam sebuah situasi terisolasi, tanpa kehadiran orang lain, dalam kondisi yang sangat tidak nyaman. Melalui tes ini, Allah membentuk daya tahan, daya juang dan mentalitas tidak mudah menyerah di dalam kehidupan seorang pemimpin. Dalam situasi seperti inilah, pemimpin menjadi sepenuhnya bergantung pada Allah dan berharap pada kemurahan, pertolongan dan kekuatan-Nya. Terbukti, dari hasil penelitian, faktor dominan kedua yang memberi pengaruh pada Ujian Kesabaran ini adalah Ujian Waktu (Time Test) di mana pemimpin dituntut 
untuk belajar sabar dan menanti penggenapan janji Tuhan di dalam hidupnya. Semakin bergantung kepada Allah, akan semakin melatih pemimpin untuk tetap memegang janji Tuhan sekalipun hidup di dalam kenyataan yang bertolak belakang daripada janji tersebut.

\section{Kesimpulan}

Berdasarkan analisis dan pembahasan di atas maka dapat ditarik kesimpulan sebagai berikut:

l. Tingkat responsif mahasiswa program pascasarjana jurusan kepemimpinan Kristen STT Harvest Semarang, berada di dalam kategori sedang-sedang saja pada nilai rentang nilai $\mu$ sebesar 37.04 sd 42.69 . Dalam rangka menaikkan tingkat responsif, diusulkan hadirnya pengetahuan atau materi tentang Tests of Leadership di dalam pembentukan kepemimpinan.

2. Aspek yang dominan memengaruhi Tests of Leadership, jika diuji serentak, adalah Ujian Padang Gurun dengan nilai Improvement tertinggi sebesar 13.176. Hal ini mengindikasikan bahwa mahasiswa program pasca sarjana jurusan kepemimpinan Kristen STT Harvest Semarang cenderung mengalami Ujian Padang Gurun (Wilderness Test) di dalam proses pembentukan nilai-nilai kepemimpinan di dalam kehidupan para mahasiswa tersebut.

\section{Kepustakaan}

Blackaby, Henry, Richard Blackaby. Kepemimpinan Rohani. Jakarta: Gospel Press, 2005.

Bolker, Benjamin M. "Combining Endogenous and Exogenous Spatial Variability in Analytical Population Models." Theoretical Population Biology 64, no. 3 (2003): 255-270. https://doi.org/10.1016/S00405809(03)00090-X

Clinton, J. Robert. Pembentukan Pemimpin Sejati. Jakarta: Metanoia, 2004.

Damazio, Frank. Making of a Leader. Portland, Oregon: City Bible Publishing, 1987.

Day, David V., John W. Fleenor, Leanne E. Atwater, Rachel E. Sturm, and Rob A. McKee. "Advances in Leader and Leadership Development: A Review of 25 Years of Research and Theory." Leadership Quarterly, 2014. https://doi.org/10.1016/j.leaqua.2013.11.004.

Riswanto, D., Jermia Djadi. "Prinsip-Prinsip Kepemimpinan Yusuf Dalam

Menghadapi Perubahan Berdasarkan Kitab Kejadian 37-50." Jurnal Jaffray 8, no. 2 (2010): 47-65. http://dx.doi.org/10.25278/jj7l.v8i2.46

Eliezer, Sasmoko. Bahan Kuliah Metode Penelitian Dan Measurement Mahasiswa 
S2 Manajemen Pendidikan Di Tana Toraja, 2006. Belum dipublikasikan. Heifetz, R. A., D. L. Laurie. "The Work of Leadership." Harvard business review 75 , no. 1 (1997): 124-134.

https://doi.org/10.1109/EMR.2009.5235495

James Manktelow. "What Is Leadership?" MindTools 55, no. 1 (2018): 1. Diakses 19 Maret 2018. https://www.mindtools.com/pages/article/newLDR_4l.htm.

Kazmier, Leonard J. Statistik Untuk Bisnis. Edited by Wisnu Candra Kristiaji. Jakarta: Erlangga, 2005.

Kouzes, James M., Barry Z. Posner. Tantangan Kepemimpinan. Jakarta: Interaksara, 2008.

Loh, Wei Yin. "Classification and Regression Trees." Wiley Interdisciplinary Reviews: Data Mining and Knowledge Discovery 1, no. 1 (2011): 14-23. http://dx.doi.org/10.1016/0169-7439(91)80113-5.

Maiaweng, Peniel C. D. "Tinjauan Teologis Tentang Takut Akan Tuhan Berdasarkan Kitab Amsal Dan Implementasinya Dalam Hidup Kekristenan." Jurnal Jaffray 10, no. 2 (2012): 118-147. http://dx.doi.org/10.25278/jj7l.vl0il.68

Maxwell, John. Mengembangkan Kepemimpinan Di Dalam Diri Anda. Jakarta: Binarupa Aksara, 1995.

Moshman, David. "Exogenous, Endogenous, and Dialectical Constructivism." Developmental Review 2, no. 4 (1982): 371-384. DOI:10.1016/0273-2297(82)90019-3.

Nouwen, Heni J. In the Name of Jesus: Reflections on Christian Leadership, 1981.

Prasetyo, Bambang and Lina M. Jannah. Metode Penelitian Kuantitatif. Jakarta: Raja Grafindo Perkasa, 2008.

Lola, S., Nelly Petronella Tuhumury. "Prinsip-Prinsip Kepemimpinan Transformatif Berdasarkan Kitab Nehemia Dan Implikasinya Bagi Kepemimpinan Rohani Masa Kini." Jurnal Jaffray 8, no. 2 (2010): 6687. http://dx.doi.org/10.25278/jj7l.v8i2.48

Sanders, J. Oswald. Kepemimpinan Rohani. Bandung: Kalam Hidup, 2017.

Stott, John. Isu-Isu Global - Tantangan Kepemimpinan Kristiani. Jakarta:

Yayasan Komunikasi Bina Kasih/OMF, 2005.

Wagemans, Johan. "Cognitive Psychology." Edited by Kimberly KempfLeonard. Encyclopedia of Social Measurement (2005): 351-359. Diakses 7 April 2018.

http://linkinghub.elsevier.com/retrieve/pii/B0123693985004801.

Zaluchu, Sonny Eli. Pengolahan Data Kuantitatif - Pendekatan Quantitative Analysis Melalui Perbandingan (Komparatif), Hubungan (Korelasional) Dan Estimasi (Regresi) Menggunakan SPSS. Semarang: Golden Gate Publishing, 2018. 